\title{
Effect of variable oceanic productivity on the survival of an upper trophic predator, the Hawaiian monk seal Monachus schauinslandi
}

\author{
Jason D. Baker ${ }^{1,2, *}$, Jeffrey J. Polovina ${ }^{1}$, Evan A. Howell ${ }^{1}$ \\ ${ }^{1}$ Pacific Islands Fisheries Science Center, National Marine Fisheries Service, NOAA, 2570 Dole St., Honolulu, Hawaii, USA \\ ${ }^{2}$ University of Aberdeen, School of Biological Sciences, Lighthouse Field Station, George Street, Cromarty, \\ Ross-shire IV11 8YJ ,UK
}

\begin{abstract}
The Hawaiian monk seal population is declining, and low juvenile survival due to prey limitation is believed to be a primary cause. The Transition Zone Chlorophyll Front (TZCF) is a largescale oceanographic feature separating the vertically stratified, low surface chlorophyll subtropical waters and the vertically mixed, cool, high chlorophyll Transition Zone waters. The TZCF annually migrates over $1000 \mathrm{~km}$ in latitude, and its southern extent in winter varies. We hypothesize that when the front migrates southward, it brings colder, more productive waters into monk seal foraging habitat, thereby enhancing the prey base and consequently survival. We expect this effect will be strongest at seal populations situated farthest north and nearest the TZCF. To test this hypothesis, we explored relationships of the survival of more than 3000 monk seals during 1984-2004 to the southernmost latitude of the $18^{\circ} \mathrm{C}$ isotherm (a proxy for the TZCF). We found a statistically significant nonlinear relationship between the winter position of the TZCF and survival of monk seals through $4 \mathrm{yr}$ of age at the most northerly atolls. When the front remained farther north, survival was poorer. The relationship was strongest following a 1 or $2 \mathrm{yr}$ lag, perhaps indicating the time required for enhanced productivity to influence the food web and improve the seals' prey base. No such relationship was found at subpopulations located farther south or among adult animals at any site. Variation in ocean productivity may mediate prey availability in monk seal foraging habitat and consequently influence juvenile survival in the northern portion of their range.
\end{abstract}

KEY WORDS: Productivity · Survival · Time lag · Northwestern Hawaiian Islands · Hawaiian monk seal

\section{INTRODUCTION}

The Northwestern Hawaiian Islands (NWHI) is an oceanic island ecosystem composed of a chain of atolls, islands and seamounts extending $1800 \mathrm{~km}$ across the subtropical Pacific. This region is generally characterized by low oceanic productivity (Mann \& Lazier 1991). The dynamics of productivity in the NWHI archipelago is poorly understood, but decadal-scale changes in productivity have been linked to variability in the mixed-layer depth, which in turn is driven by the Aleutian Low Pressure System (Polovina et al. 1994, 1995). Schmelzer
(2000) summarized a variety of oceanographic parameters, which, within the NWHI, indicated a gradient of higher-to-lower productivity from north to south.

The endangered Hawaiian monk seal Monachus schauinslandi has been the subject of long-term demographic research. The species is distributed throughout the NWHI and is concentrated in 6 main subpopulations spanning the width of the archipelago. While monk seals come on land to rest and rear their offspring, they forage on nearly every reef, bank, and submerged seamount within approximately $500 \mathrm{~m}$ of the surface in the NWHI (Stewart et al. 2006). 
More than 20 yr of individual monk seal sighting histories indicate considerable fluctuation in survival rates, both temporally and spatially, though the causes of this variation are unknown (Baker \& Thompson 2007). However, periods of low juvenile monk seal survival appear to be related to food limitation (Craig \& Ragen 1999).

To better understand NWHI ecosystem dynamics and also aid in the conservation of the monk seal, it is imperative that the underlying drivers of variable vital rates in this imperiled species are discovered. Polovina et al. $(1994,1995)$ found that a regime shift in the late 1980s, marking a transition to a shallower mixed-layer depth and lower primary productivity in the NWHI, was associated with decline in survival and productivity at higher trophic levels (lobsters, seabirds and monk seals) at one NWHI location, French Frigate Shoals. Antonelis et al. (2003) found that monk seal pup girth at weaning was greater in El Niño years than non-El Niño years, suggesting that short-term fluctuations in ocean conditions influence monk seals. Building on this foundation, in the present study we focus on the Transition Zone Chlorophyll Front (TZCF), a largescale oceanographic feature separating the vertically stratified, low surface chlorophyll subtropical waters and the vertically mixed, cool, high chlorophyll Transition Zone waters. The TZCF annually migrates over $1000 \mathrm{~km}$ in latitude and its southern extent in winter varies (Bograd et al. 2004). The frontal region is associated with surface convergence, thereby likely concentrating resources throughout the food chain (Polovina et al. 2001).

We hypothesized that the TZCF represents a possible mechanism for variable NWHI ecosystem productivity, and consequently, variable monk seal survival. We expected that in years when the front extends farther south in winter, it bathes the NWHI in more productive waters, thereby increasing productivity throughout the food web and ultimately resulting in greater prey availability and survival of monk seals. Conversely, when the front remains farther north, NWHI waters are relatively unproductive, ultimately resulting in lower juvenile survival. Three additional expectations follow if our central hypothesis is true. First, the effects of the TZCF variability should be most pronounced in the northerly portion of the archipelago most proximate to the front. Second, juvenile Hawaiian monk seals should be most affected by changes in productivity, as they are relatively inexperienced foragers, have limited diving capabilities relative to older animals (and thereby have fewer alternative foraging strategies when prey is scarce), have lower tolerance for food limitation due to their smaller size (Millar \& Hickling 1990) and exhibit more variable survival rates (Baker \& Thompson 2007). Third, the relationship of changes in the latitude of the TZCF to seal survival should involve a time lag, allowing for the propagation of presumed fluctuations in primary productivity up through the food web to result in altered monk seal prey availability.

\section{MATERIALS AND METHODS}

Monk seal survival. We used estimates of Hawaiian monk seal survival presented by Baker \& Thompson (2007). Since 1984, weaned pups were double-marked with unique plastic rear flipper tags in their year of birth. Subsequent resighting efforts occurred during typically 2 to 5 mo long field seasons through 2004 at each of the 6 main NWHI subpopulations. Tag and resight effort at one site, Midway Atoll, began in the late 1980s, as there had been few or no births in previous years. Individual identities were maintained through a redundant system involving re-tagging, photographic and hand-drawn documentation of scars and other natural markings, and temporary bleach marks applied to the seals' fur (Harting et al. 2004).

Individual sighting histories were constructed from the tag and resighting records and maximum likelihood estimates (MLE) of survival rates and capture probabilities were obtained using the 'recaptures only' analysis implemented in Program MARK (White \& Burnham 1999). In the present paper, first year survival refers to survival from weaning to age $1 \mathrm{yr}$, second year survival refers to survival from age 1 to $2 \mathrm{yr}$, etc. Baker \& Thompson (2007) found that patterns of monk seal survival rates were lowest from weaning through the second year, then increased through the fourth year, and leveled off from age 5 to $17 \mathrm{yr}$, before a senescent decline occurred. Significant time variance was detected for all but the oldest (18 to $20 \mathrm{yr}$ old) age groups. Spatial patterns were also evident as French Frigate Shoals survival rates were different from other sites for all except the oldest senescent age group. Pearl and Hermes, Midway and Kure survival rates were indistinguishable from each other at all ages. Laysan and Lisianski Islands did not significantly differ from each other, with the exception that the youngest animals' (first and second year) survival at Lisianski Island was more similar to rates at Pearl and Hermes, Midway and Kure. Finally, at French Frigate Shoals only, females exhibited higher survival than males. For this study, we compared estimated survival rate time series for each of these groups with distinct survival rate trends to variability in the TZCF (Table 1).

TZCF dynamics. The northern atolls of the NWHI lie at the boundary between the subtropical gyre and the Transition Zone. This boundary is dynamic and in the winter is characterized by several fronts. The TZCF is a 
Table 1. Monachus schauinslandi. Twelve combinations of age/subpopulation/ sex groups with distinct temporal trends in Hawaiian monk seal survival rates (from Baker \& Thompson 2007). Northwestern Hawaiian Islands subpopulations: French Frigate Shoals (FFS), Laysan Island (LAY), Lisianski Island (LIS), Pearl and Hermes Reef (PHR), Midway Atoll (MDY), and Kure Atoll (KUR). Sex differences in survival were found only at FFS

\begin{tabular}{|c|c|c|c|c|}
\hline Age group (yr) & & $-\mathrm{Su}$ & ulation / S & group \\
\hline $1-2$ & FFS o & FFS $0^{7}$ & LAY & PHR+MDY+KUR+LIS \\
\hline $3-4$ & FFS & FFS $\sigma^{7}$ & LAY+LIS & PHR+MDY+KUR \\
\hline $5-17$ & FFS o & FFS $\sigma^{7}$ & LAY+LIS & $\mathrm{PHR}+\mathrm{MDY}+\mathrm{KUR}$ \\
\hline
\end{tabular}

strong temperature front and an abrupt shoaling of the deep chlorophyll maximum from about $100 \mathrm{~m}$ in the south to about $50 \mathrm{~m}$ in the north (Seki et al. 2002).

For 1997, chlorophyll a data collected by the Ocean Color and Temperature Scanner (OCTS) on the ADEOS satellite were used. From September 1997 to present, we used chlorophyll a data collected by the Sea-viewing Wide Field-of-view Sensor (SeaWiFS) instrusurface chlorophyll front, identified as the latitude corresponding to the surface chlorophyll level of $0.2 \mathrm{mg}$ chl m${ }^{-3}$ (Fig. 1, Polovina et al. 2001). North of Hawaii the TZCF also corresponds very closely to the position of the $18^{\circ} \mathrm{C}$ sea surface temperature (SST) isotherm (Bograd et al. 2004). Since satellite-derived surface chlorophyll records became available only in late 1997, we used the $18^{\circ} \mathrm{C} \mathrm{SST}$ proxy for the position of the TZCF to extend our time series of the latitude of the TZCF back to 1982 . While the TZCF is very visible from satellite surface chlorophyll data, a second front south of the TZCF in the winter, termed the South Subtropical Front (SSTF), is located from the latitude of the $20^{\circ} \mathrm{C} \mathrm{SST}$ isotherm (Seki et al. 2002). While the SSTF does not have a surface expression in chlorophyll, it represents a ment on board the Seastar spacecraft. This product is derived from the raw measured wavelength bands using the SeaWiFS algorithm (SeaWiFS L3 CHLO product). Both chlorophyll a products used in this study are a $9 \mathrm{~km}$ pixel resolution product on an equidistant cylindrical projection distributed as version 4 .

Reynolds' optimally interpolated SST data were used to derive SST proxies for the TZCF and SSTF. This interpolated analysis incorporated data collected by Advanced Very High Resolution Radiometers (AVHRR) on board NOAA polar orbiting satellites with in situ data derived from both ship and buoys. Both these datasets are optimally interpolated (Reynolds \& Smith 1994) onto a $1^{\circ} \times 1^{\circ}$ grid as a monthly product with an accuracy of $\pm 0.5^{\circ} \mathrm{C}$. To construct the SST-

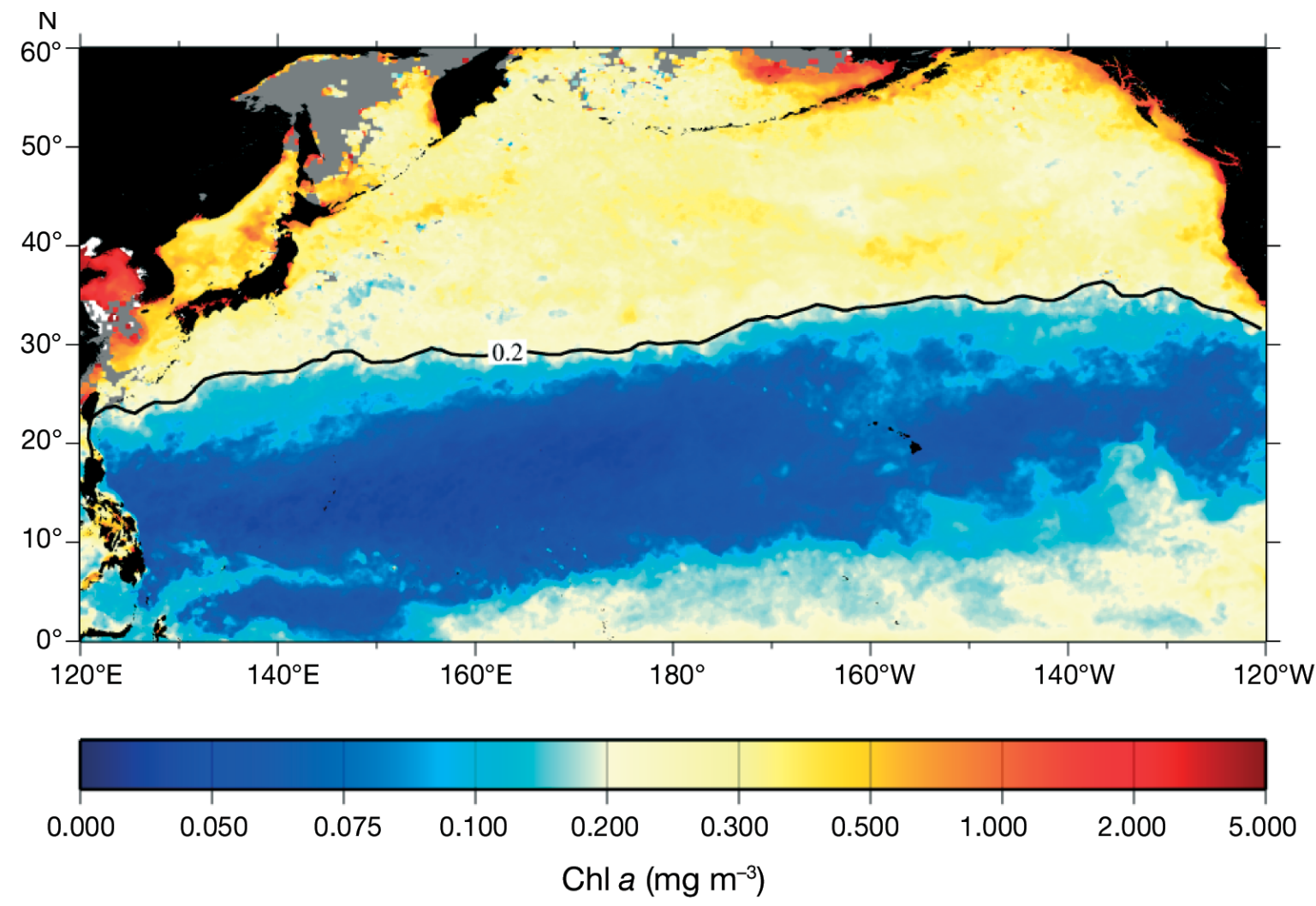

Fig. 1. Surface chlorophyll estimates from SeaWiFS ocean color over the North Pacific for February 2000. Black line represents the $0.2 \mathrm{mg}$ chlorophyll $\mathrm{m}^{-3}$ surface contour indicating the Transition Zone Chlorophyll Front (TZCF) 
based proxy indicators used in our study, the minimum latitudinal position of the 18 and $20^{\circ} \mathrm{C} \mathrm{SST}$ isotherms were calculated from each monthly dataset to construct a time series from 1982 to 2004.

Statistical analysis. We analyzed the support for a relationship between the $18^{\circ} \mathrm{C}$ SST isotherm's southernmost latitude and the survival rate time series representing all combinations of 3 age groups and 4 subpopulation/sex groups identified as distinct by Baker \& Thompson (2007) (Table 1). For each cell in Table 1, we fitted 7 models: a null model (no predictor), 3 linear models (with the $18^{\circ} \mathrm{C}$ SST isotherm as a predictor lagged by 0,1 and 2 yr), and to allow for non-linearity in the relationship, 3 generalized additive models (GAMs) with 2 degrees of freedom, also lagged by 0, 1, and 2 yr. Models were ranked and their relative support evaluated using the small-sample corrected Akaike's information criterion $\left(\mathrm{AIC}_{\mathrm{c}}\right)$ and Akaike weights $\left(w_{i}\right)$ (Anderson et al. 2000). Models were fitted using the 'gam' package in the statistical software program R (Version 2.1.1).

Preliminary survival estimates subsequent to 2004 (the last year analyzed by Baker \& Thompson 2007) were also calculated. These are considered minimum survival rates because they are based upon only 1 or 2 yr of resight effort. As such, they are not included in the statistical analysis described above, but are presented to provide the most up-to-date information available.

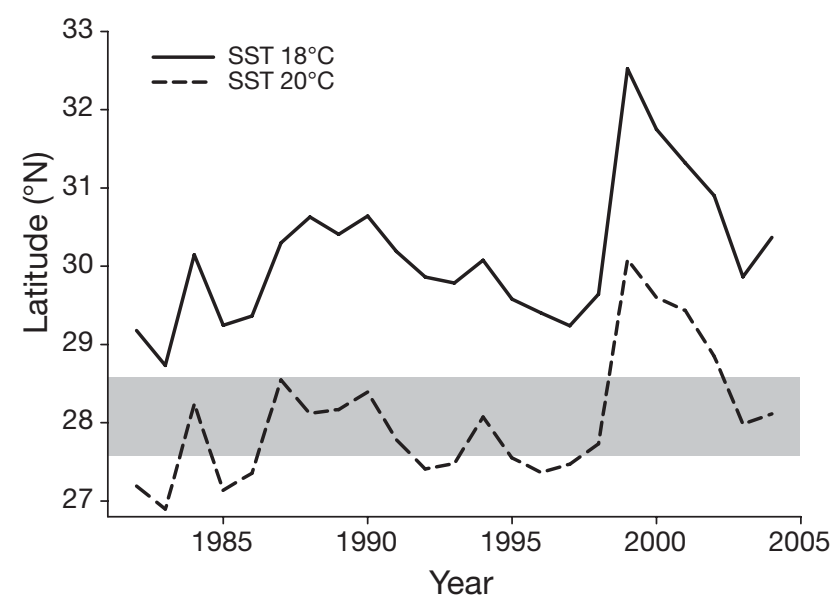

Fig. 3. Temporal trend in the southernmost extent of the Transition Zone Chlorophyll Front (TZCF) as indicated by the 18 and $20^{\circ} \mathrm{C}$ sea surface temperature (SST) isotherms. Shaded box indicates the latitudinal ranges of the 3 northernmost NWHI atolls: Pearl and Hermes, Midway, and Kure

\section{RESULTS}

As noted previously (Bograd et al. 2004), there has been considerable variability in the wintertime southern extent of the TZCF (Figs. $2 \& 3$ ). The positions of the 18 and $20^{\circ} \mathrm{C} \mathrm{SST}$ isotherms were highly correlated $\left(\mathrm{r}^{2}=0.94\right)$ such that they are essentially equivalent indicators of the same phenomenon. In most years, the subsurface chlorophyll maximum, as indicated by the

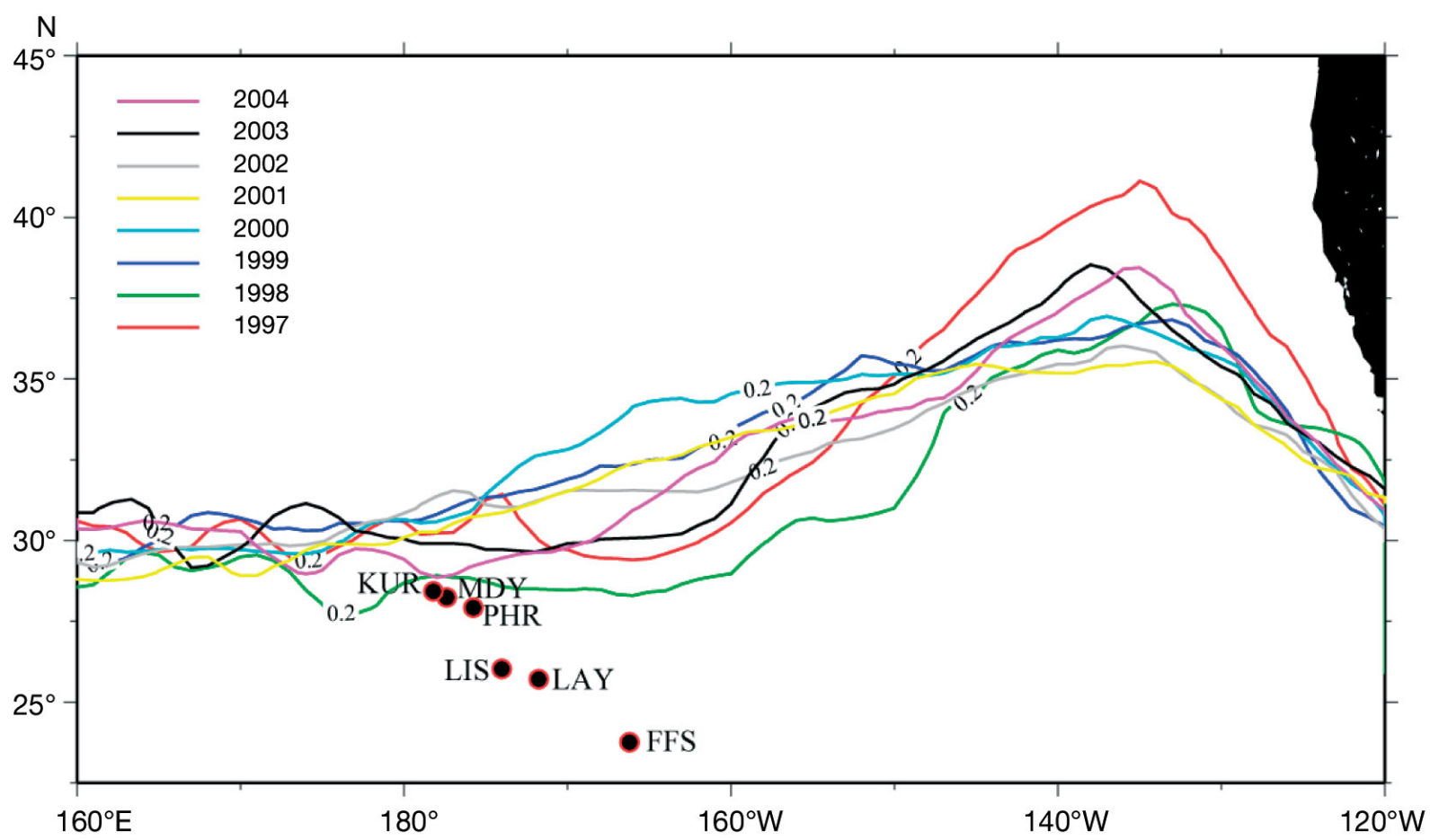

Fig. 2. Annual variation in the January-February location of the $0.2 \mathrm{mg}$ chlorophyll $\mathrm{m}^{-3}$ countour, 1997-2004. KUR: Kure Atoll; MDY: Midway Atoll; PHR: Pearl and Hermes Reef; LIS: Lisianski Island; LAY: Laysan Island; FFS: French Frigate Shoals 
Table 2. Monachus schauinslandi. Modeling results indicating statistical support for relationships between the Transition Zone Chlorophyll Front (TZCF) and monk seal survival the same year, and lagged by 1 or 2 yr. Linear (LM) and generalized additive models (GAM) are compared to each other and a null model (null: no predictor) using the difference in small sample Akaike's Information Criterion $\left(\Delta \mathrm{AIC}_{\mathrm{c}}\right)$ and Akaike weights $\left(w_{i}\right)$. Models are presented in order with the most supported (lowest $\mathrm{AIC}_{\mathrm{c}}$ ) first

\begin{tabular}{|lccccc|}
\hline Model type & Time lag (yr) & $\mathrm{df}$ & $\mathrm{AIC}_{\mathrm{c}}$ & $\Delta \mathrm{AIC}_{\mathrm{c}}$ & $W_{i}$ \\
\hline (a) 1st and 2nd year survival at Lisianski, Pearl and Hermes, Midway and \\
Kure Atoll (N = 20) \\
GAM & 2 & 3 & -17.67 & 0 & 0.59 \\
LM & 2 & 2 & -15.01 & 2.66 & 0.16 \\
GAM & 1 & 3 & -14.64 & 3.04 & 0.13 \\
LM & 1 & 2 & -14.24 & 3.44 & 0.11 \\
Null & - & 1 & -9.10 & 8.57 & 0.01 \\
LM & 0 & 2 & -8.57 & 9.10 & 0.01 \\
GLM & 0 & 3 & -8.27 & 9.40 & 0.01 \\
(b) 3rd and 4th year survival at Pearl & and Hermes, Midway & and Kure Atoll \\
(N = 18) & 1 & & & & \\
GAM & 2 & 3 & -56.44 & 0 & 0.64 \\
GAM & 0 & 3 & -53.71 & 2.73 & 0.16 \\
GAM & 2 & 2 & -51.46 & 4.44 & 0.07 \\
LM & 1 & 2 & -50.50 & 5.98 & 0.05 \\
LM & - & 1 & -50.29 & 6.15 & 0.03 \\
Null & 0 & 2 & -49.07 & 7.37 & 0.03 \\
LM & & & & & \\
\end{tabular}

additive model (GAM) with a 2 yr time lag (Fig. 4a) had far more support than the null model $\left(\Delta \mathrm{AIC}_{\mathrm{c}}=8.6\right)$ and the most support among all models tested $\left(w_{i}=0.59\right)$. Linear fits with 1 and $2 \mathrm{yr}$ lags and a GAM with a 1 yr lag had somewhat less support than the GAM with a 2 yr lag. There was a similar relationship between third and fourth year survival at Pearl and Hermes, Midway and Kure and the southern reach of the TZCF $\left(\triangle \mathrm{AIC}_{\mathrm{C}}=6.2\right.$ relative to the null model, $\left.w_{i}=0.64\right)$. In this case, a GAM with a 1 yr lag fitted best, and a 2 yr lag had somewhat less support (Table 2, Fig. 4b).

Survival of adults (Age 5 to $17 \mathrm{yr}$ ) at the northernmost atolls was not statistically associated with the TZCF trend, nor was any such association found for survival of any age group at the other monk seal subpopulations. For all these remaining subpopulation/age groups, the null model was the best fit or had $\Delta \mathrm{AIC}_{\mathrm{c}}$ values only marginally larger

$20^{\circ} \mathrm{C}$ isotherm (Seki et al. 2002), intersected the latitudes where the 3 most northerly atolls are situated.

A rather strong inverse relationship was found between first and second year survival of monk seals at the most northerly sites (Lisianski, Pearl and Hermes, Midway and Kure) and the southernmost latitude of the TZCF (Table 2) after a time lag. A generalized
$(<1.3)$ than the lowest $\mathrm{AIC}_{\mathrm{c}}$ value. To elucidate patterns in the relationship between the front's wintertime position and monk seal survival, we examined the simple linear correlation coefficients (r) between the TZCF and survival time series for all subpopulation/age groups with 0,1 , and 2 yr lags. Fig. 5 reveals that most of the correlations were negative, and that the magni-

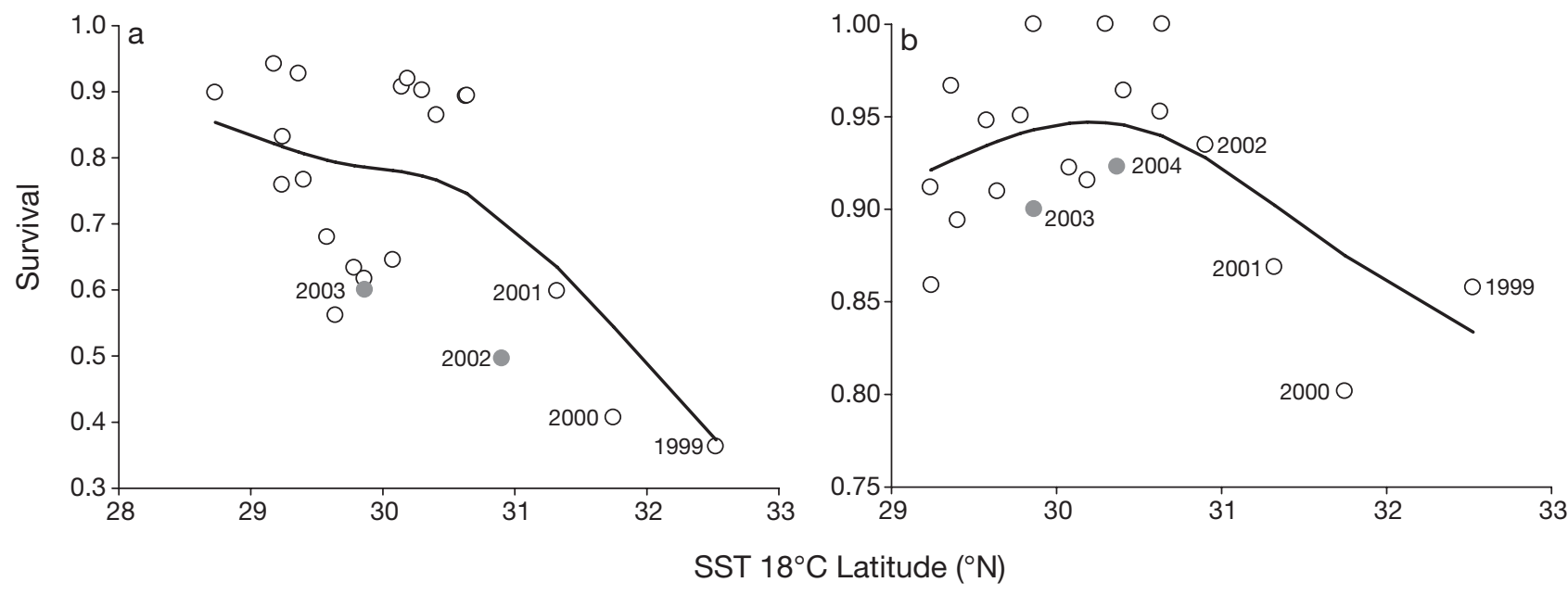

Fig. 4. Monachus schauinslandi. Relationship between the southernmost wintertime latitude of the Transition Zone Chlorophyll Front (TZCF, as indicated by the $18^{\circ} \mathrm{C}$ sea surface temperature [SST] isotherm) and survival of Hawaiian monk seals lagged by (a) 2 yr for first and second year seals at Lisianski Island, Pearl and Hermes Reef, Midway Atoll and Kure Atoll, and (b) 1 yr for third and fourth year seals at Pearl and Hermes Reef, Midway Atoll and Kure Atoll. Solid lines: generalized additive model (GAM) fits. Consecutive years (1999-2001) when the front remained furthest north are identified. ๑: TZCF's position in 2002-2004 and recent preliminary (minimum) survival estimates lagged as noted above 

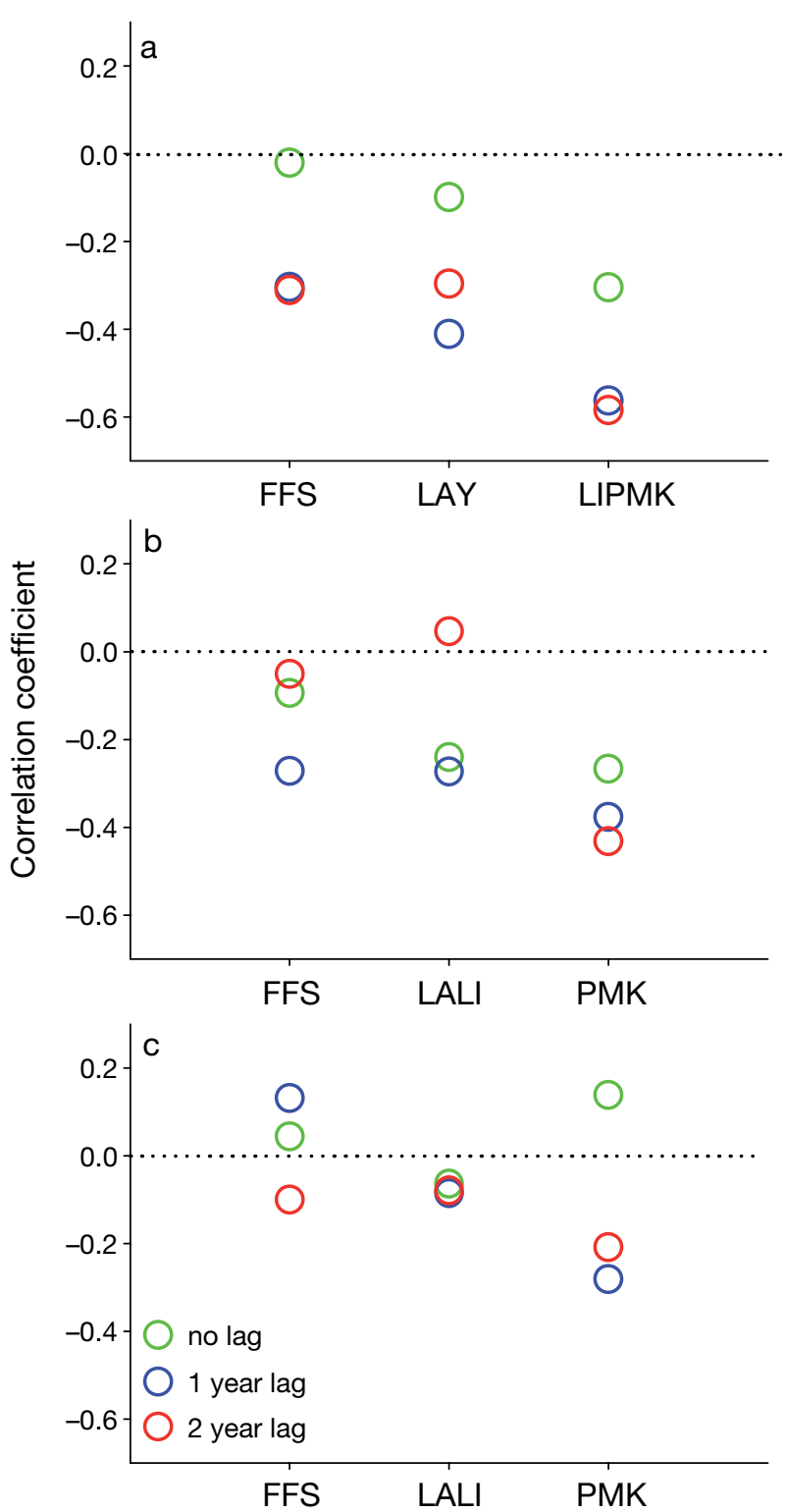

Fig. 5. Monachus schauinslandi. Simple linear correlation coefficients (r) between the southernmost wintertime latitude of the Transition Zone Chlorophyll Front (TZCF, as indicated by the $18^{\circ} \mathrm{C}$ sea surface temperature [SST] isotherm) and survival trends of (a) first and second year seals, (b) third and fourth year seals, and (c) 5 to 17 yr old Hawaiian monk seals, lagged by 0 to $2 \mathrm{yr}$. Three subpopulation groups for each panel are arrayed on the $x$-axis. FFS: French Frigate Shoals; LAY: Laysan Island; LIPMK: Lisianski Islands grouped with PMK; LALI: Laysan and Lisianski Islands; PMK: Pearl and Hermes Reef, Midway Atoll and Kure Atoll

tude of the correlations tended to be greatest for the youngest ages (Years 1 and 2), somewhat less for Years 3 and 4, and lowest for the adults (Age 5 to $17 \mathrm{yr}$ ). There was also a tendency for correlations to strengthen moving from the southern to the northern portion of the archipelago (i.e. from French Frigate
Shoals through to Pearl and Hermes, Midway and Kure). Finally, at the northern subpopulations, the correlation of survival with the TZCF tended to strengthen after a 1 or 2 yr time lag. The only statistically significant linear correlations were among the youngest animals at the northern subpopulations after a $1 \mathrm{yr}(\mathrm{p}=0.01)$ and $2 \mathrm{yr}(\mathrm{p}=0.007)$ lag.

\section{DISCUSSION}

Our results accord remarkably well with our a priori expectations. The relationship between survival and the southern extent of the front was inverse as expected; statistical significance was detected only for young animals at the northern atolls most proximate to the front, and only after a time lag. Further, the pattern in correlations (Fig. 5) was consistent with a graduated effect across latitude and seal age. The statistical support for the relationships depicted in Fig. 4 is largely a result of 3 consecutive years (1999 to 2001), in which the TZCF remained further north than in all other years of our study, and which were followed by $3 \mathrm{yr}$ of unusually poor survival. This raises the possibility that the apparent relationship may not be cause and effect, rather an artifact of 2 auto-correlated time series. However, after 2001, the TZCF shifted back further south and subsequently preliminary minimum survival estimates increased (gray points in Fig. 4). Additionally, the fact that this relationship was only observed for young animals in the northern portion of the archipelago after a time lag suggests that it is not spurious. Future monitoring of both monk seal survival and central North Pacific oceanography will likely continue to clarify this issue.

The mechanisms by which the dynamics of the TZCF influence monk seal survival are uncertain. Based upon tracking and diving studies, monk seals appear to be benthic, and not pelagic foragers (Parrish et al. 2000, 2002, 2005, Stewart et al. 2006). We therefore do not think that the seals track the TZCF directly and forage on associated prey as other predators appear to do (Polovina et al. 2001). Rather, we hypothesize that when the front moves farther south, it raises primary productivity in the northern NWHI (Fig. 3), which eventually propagates vertically through the food web to increase monk seal prey availability. Parrish et al. (2005) found that juvenile monk seals tend to forage on sand banks and generally take small $(<10 \mathrm{~cm})$ cryptic, benthic prey. They proposed that conditions which affect the settlement of larval fishes on sand banks could be a link between oceanography and juvenile monk seal survival. This presents a testable hypothesis that the dynamics of the TZCF influence the abundance or growth of larval fishes on sand banks in the NWHI. 
An analogous coupling of oceanographic variability and vital rates of an endangered marine mammal occurs in the northwestern Atlantic (Greene \& Pershing 2004). Variability in the North Atlantic Oscillation (NAO) Index influences water temperatures in the Gulf of Maine and Scotian Shelf regions, which in turn drives the abundance of the copepod Calanus finmarchicus. This is the primary prey of the endangered North Atlantic right whale, and C. finmarchicus abundance influences the whales' reproductive rates. This system involves a 1 to 2 yr time lag between changes in oceanography and reproductive rates, similar to what we have observed in monk seals.

The 1 to 2 yr lapse between a northerly shift of the TZCF and reduced seal survival could prove opportune for monk seal conservation efforts. In the past, undersized young seals have been fattened up in captivity and released back into the wild at sites experiencing favorable conditions. Recent declines in monk seal survival, especially in the northern portion of the NWHI (Baker \& Thompson 2007), have generated renewed interest in rehabilitation and release programs. Monitoring excursions of the TZCF may serve as a valuable early warning signal of poor survival 1 to 2 yr hence, thereby allowing management interventions to be scheduled when they are most needed.

The drivers of variable productivity and consequent status of biological communities in the NWHI ecosystem remain largely unknown. Polovina et al. (1994, 1995) first provided evidence that decadal scale shifts in the North Pacific influence NWHI organisms at a whole range of trophic levels. Our analyses indicate that oceanographic variability on a shorter time scale also influences at least the northern NWHI. In fact, the dynamics described by Polovina et al. $(1994,1995)$ and those presented in the present study are essentially one and the same, differing only in the magnitude of change and time scales over which they occur.

Acknowledgements. We are grateful to J. Laake for his consultation on the statistical approach used in this study. We thank B. Antonelis, A. Harting, and P. Thompson for their helpful reviews. Field research was conducted in the Hawaiian Islands and Midway Atoll National Wildlife Refuges (managed by the US Fish and Wildlife Service) and the State of Hawaii wildlife preserve at Kure Atoll.

\section{LITERATURE CITED}

Anderson DR, Burnham KP, Thompson WL (2000) Null hypothesis testing: problems, prevalence, and an alternative. J Wildl Manag 64:912-923

Antonelis GA, Baker JD, Polovina JJ (2003) Improved body condition of weaned Hawaiian monk seal pups associated with El Niño events: potential benefits to an endangered species. Mar Mamm Sci 19:590-598

Baker JD, Thompson PM (2007) Temporal and spatial variation in age-specific survival rates of a long-lived mammal, the Hawaiian monk seal. Proc R Soc Lond Ser B 274: 407-415

Bograd SJ, Foley DG, Schwing FB, Wilson C, Laurs M, Polovina JJ, Howell EA, Brainard RE (2004) On the seasonal and interannual migrations of the transition zone chlorophyll front. Geophys Res Lett 31:L17204

Craig MP, Ragen TJ (1999) Body size, survival, and decline of juvenile Hawaiian monk seals, Monachus schauinslandi. Mar Mamm Sci 15:786-809

Greene $\mathrm{CH}$, Pershing AJ (2004) Climate and the conservation biology of North Atlantic right whales: the right whale at the wrong time? Front Ecol Environ 2:29-34

Harting AL, Baker JD, Becker BL (2004) Nonmetrical digital photo identification system for the Hawaiin monk seal. Mar Mamm Sci 20:886-895

Mann KH, Lazier JRN (1991) Dynamics of marine ecosystems: biological-physical interactions in the oceans. Blackwell Scientific Publications, Oxford

Millar JS, Hickling GJ (1990) Fasting endurance and the evolution of mammalian body size. Funct Ecol 4:5-12

Parrish FA, Craig MP, Ragen TJ, Marshall GJ, Buhleier BM (2000) Identifying diurnal foraging habitat of endangered Hawaiian monk seal using a seal-mounted video camera. Mar Mamm Sci 16:392-412

Parrish FA, Abernathy K, Marshall GJ, Buhleier BM (2002) Hawaiian monk seals (Monachus schauinslandi) foraging in deep-water coral beds. Mar Mamm Sci 18:244-258

Parrish FA, Marshall GJ, Littnan CL, Heithaus M, Canja S, Becker B, Braun R, Antonelis GA (2005) Foraging of juvenile monk seals at French Frigate Shoals, Hawaii. Mar Mamm Sci 21:93-107

Polovina JJ, Mitchum GT, Graham NE, Craig MP, DeMartini EE, Flint EN (1994) Physical and biological consequences of a climate event in the central North Pacific. Fish Oceanogr 3:15-21

Polovina, JJ, Mitchum GT, Evans GT (1995) Decadal and basin-scale variation in mixed layer depth and the impact on biological production in the Central and North Pacific, 1960-1988. Deep-Sea Res 42:1701-1716

Polovina JJ, Howell E, Kobayashi DR, Seki MP (2001) The Transition Zone chlorophyll front, a dynamic global feature defining migration and forage habitat for marine resources. Prog Oceanogr 491:469-483

Reynolds RW, Smith TM (1994) Improved global sea surface temperature analyses using optimum interpolation. J Clim $7: 929-948$

Schmelzer I (2000) Seals and seascapes: covariation in Hawaiian monk seal subpopulations and the oceanic landscape of the Hawaiian Archipelago. J Biogeogr 27:901-914

Seki MP, Polovina JJ, Kobayashi DR, Bidigare RR, Mitchum GT (2002) An oceanographic characterization of swordfish (Xiphias gladius) longline fishing grounds in the springtime subtropical North Pacific. Fish Oceanogr 11:251-266

Stewart BA, Antonelis GA, Baker JD, Yochem PY (2006) Foraging biogeography of the Hawaiian monk seal in the Northwestern Hawaiian Islands. Atoll Res Bul 543: 131-145

White GC, Burnham KP (1999) Program MARK: survival estimation from populations of marked animals. Bird Study (Suppl) 46:120-139

Submitted: September 18, 2006; Accepted: March 13, 2007

Proofs received from author(s): September 5, 2007 